Web 2.0 / Dennis JCB Revised Influences of Social eShopping Final 25.4.10 This is a preprint (pre peer-review) version of a paper accepted in its definitive form by the Journal of Customer Behaviour, (C Westburn Publishers Ltd, http://www.westburnpublishers.com and has been posted by permission of Westburn Publishers Ltd for personal use, not for redistribution. The article will be published in the Journal of Customer Behaviour, Volume 9, Issue 2: 151-174 (2010). The definitive version of the paper can be accessed from http://ejournals.ebsco.com/Article.asp?ContributionlD=21771995.

\title{
The Influences of Social e-Shopping in Enhancing Young Women's Online Shopping Behaviour
}

* Charles Dennis ${ }^{1}$, Alesia Morgan ${ }^{2}$, Len Tiu Wright ${ }^{3}$ and Chanaka Jayawardhena ${ }^{4}$

\author{
${ }^{1}$ Brunel University, \\ Uxbridge UB8 3PH \\ UK \\ Tel: +44 (0) 185265242 \\ e-mail: charles.dennis@ brunel.ac.uk \\ ${ }^{2}$ Sales and Marketing Executive \\ UltraSoft Technologies Ltd.
}

1A New Road, The Causeway, Staines, Middlesex, TW18 3DH, UK

Tel: +44 1784438922

Fax: +44 1784438923

e-mail: amorgan@ultrasoft-tech.co.uk

${ }^{3}$ Leicester Business School at Bede Island

De Montfort University

The Gateway

Leicester

LE1 9BH

UK

Tel: +44 (0)116 2506096

Fax: +44 (0)1162506329

e-mail: 1wright@dmu.ac.uk

${ }^{4}$ Senior Lecturer in Marketing

Loughborough University Business School

Leicestershire LE11 3TU, UK.

Tel. +44 (0)1509 228831

Fax. +44 (0)1509 223960

e-mail: c.jayawardhena@lboro.ac.uk

* Corresponding author 


\title{
The Influences of Social e-Shopping in Enhancing Young Women's Online Shopping Behaviour
}

\begin{abstract}
The background to this paper is that shoppers, particularly women, are motivated by a variety of different reasons, including socialising and enjoyment. Despite the growth of Internet retailing (e-retailing), these social needs are largely unmet in e-shopping. In the high street, women do most of the shopping but online shopping (e-shopping) tends to be dominated by male shoppers. At the same time, social networking is growing fast and is especially popular amongst young females. The purpose of this paper is to draw on prior research about why people shop in order to explore the concept of social e-shopping, based on combining eshopping with social networking. We propose that shoppers, particularly young females, will prefer social e-shopping to traditional e-shopping. We carried out a qualitative study for our propositions with a comparison experiment, semi-structured questionnaire and focus group, to compare a traditional e-shopping website with a social e-shopping one. The findings reveal that young women prefer social e-shopping sites. Both utilitarian and hedonic young adult female shoppers found social e-shopping enjoyable and useful. However, although many participants found the social e-shopping site more difficult to use, this was outweighed by their enjoyment of the site and its usefulness. The study demonstrates the potential value of the concept of social e-shopping for future research. The findings have practical implications in that social e-shopping can be a valuable strategy for e-retailers wanting to gain competitive advantage and to positively increase the e-shopping behaviour intentions of young women. This study is original in being the first academic study of which we are aware to propose the concept of social e-shopping and examine the influences of social e-shopping on consumer shopping behaviour.
\end{abstract}

Key words: Social e-shopping, social networking, Web 2.0, social shopping, online shopping, e-retailing.

Paper type: Conceptual/research paper.

\section{AUTHOR BIOGRAPHIES}

Charles Dennis is a Senior Lecturer at Brunel University, London, UK. His teaching and research area is (e-)retail and consumer behaviour - the vital final link of the Marketing process - satisfying the end consumer. Charles is a Chartered Marketer and has been elected as a Fellow of the Chartered Institute of Marketing for work helping to modernise the teaching of the discipline. Charles was awarded the Vice Chancellor's Award for Teaching Excellence for improving the interactive student learning experience. Charles's publications include Marketing the e-Business, $\left(1^{\text {st }} \& 2^{\text {nd }}\right.$ editions) (joint-authored with Dr Lisa Harris), the research-based $e$-Retailing (joint-authored with Professor Bill Merrilees and Dr Tino Fenech) and research monograph Objects of Desire: Consumer Behaviour in Shopping Centre Choice. His research into shopping styles has received extensive coverage in the popular media. 
Alesia Morgan is a member of the Chartered Institute of Marketing (CIM) with three years experience working in the marketing industry. She currently works as a Sales and Marketing Executive at UltraSoft Technologies, a leading provider of software solutions to all organisations. Today, she also enjoys writing blogs and articles offering practical advice for small and medium businesses (SMEs) to plan, review and improve marketing and sales process. Prior to her current position, Alesia achieved a First Class Honours, Business and Management - Marketing Degree at Brunel University in 2008. She has several personal achievements, to note a few; Media Awards for Most Promising Student at A2 Level (2004), Success Story for Enfield College Prospectus (2004-2005), Certificate of Excellence as a 'Millennium Volunteer' (2005), Student Radio Show Presenter (2006) and Head of Marketing Team for Brunel Radio Station (2007-2008). Alesia is working towards a Chartered Marketer Status from CIM and has plans to complete a Masters in Digital Marketing Communications (MSc) in the near future.

Len Tiu Wright is Professor of Marketing and Research Professor at De Montfort University, Leicester and has held full time appointments at the universities of Keele, Birmingham and Loughborough as well as guest lecturing at institutions in the UK e.g. Cambridge University and overseas. Len Tiu has retailing, consultancy and industrial experience and has researched in the Far East, Europe and North America. Her writings have appeared in books, in American and European academic journals, and at conferences where some have gained best paper awards. She is on the editorial boards of a number of leading marketing journals. She is the Founding Editor of the Qualitative Market Research - An International Journal, an Emerald publication.

Chanaka Jayawardhena is Senior Lecturer in Marketing at Loughborough University Business School, UK. He has won numerous research awards including two Best Paper Awards at the Academy of Marketing Conference. Previous publications have appeared (or forthcoming) in the Industrial Marketing Management, European Journal of Marketing, Journal of Marketing Management, Journal of General Management, Journal of Internet Research, European Business Review, among others.

\section{INTRODUCTION}

In the traditional world, women do most of the shopping but online, it is the reverse (Ballard and Mander, 2006; Dennis et al., 2002b; OFT, 2007). Why should this be? Could it be that that online shopping (e-shopping) lacks the social experience of brick and mortar shopping? There is evidence that females and in particular, young adults, regard the social aspect of shopping as an important element (e.g. Dholakia 1999). Kolesar and Galbraith (2000) found that Internet retailers (e-retailers) have difficulty in satisfying customers' higher-level needs for personal interaction. Yet the Internet is the new social space for young females (Anonymous 2007; Social Networks 2007). We suggest that there is a major opportunity for e-retailers to combine social networking with e-shopping.

e-Shopping is growing worldwide, having topped US\$100 billions in the US by 2006 (Seock and Bailey 2008) and $£ 20$ billions in the UK (OFT 2007). Eighteen percent of UK adults now e-shop at least once per week (OFT 2007) and 56\% have e-shopped at least once during the past year (Dutton et al./OxIS, 2009). In the UK, e-shopping volumes are continuing with double-digit growth up 15\% year-on-year (Deloitte 2007; IMRG/Capgemini 2010), whereas traditional bricks shopping is barely creeping back from recession with less than a third of 
that growth rate, currently $4.4 \%$ year-on-year (BRC, 2010). Competition amongst e-retailers vying to share in this new market is high. Marketers are constantly on the lookout for new ways of identifying distinct profitable customer segments so that they can better target them. Once such segments are identified, retailers are better able to position their products and services to the needs and wants of such segments, and by extension gain competitive advantage in the e-retailing marketplace.

Traditional research in retailing suggests that people can basically be divided into utilitarian and hedonic shoppers (Babin et al. 1994). These two different types of consumers display distinct shopping patterns. It should be stressed that these two shopping motives do not necessarily exclude one another and shoppers are not necessarily polarised as one or the other. Rather, it is possible that shoppers follow both motives at different points in time (Holbrook and Hirschman 1982; Babin et al. 1994). In addition, product classes (e.g. clothing vs. technical equipment) may have different influences on shopping motivation (Wang et al. 2007). Despite uncertainty over the nature of shopping motivation (e.g. trait vs. state), this is an important topic to study as retailers will be expected to satisfy shoppers better if they can understand and address their motivations. Therefore, we pose the question whether young adult females who are using e-shopping would self-classify themselves as utilitarian or hedonic shoppers? If so, do utilitarian and hedonic shoppers behave differently within the eshopping environment? Therefore, the specific objectives of our research are: first, to enquire whether distinct utilitarian and hedonic shopping segments for young adult females can be identified. If such segments exist do they display varying attitudes towards social e-shopping sites? Second, what specific attributes act as antecedents to e-shopping attitudes and intentions? In the following sub-sections, we briefly discuss the background literature regarding social aspects of shopping and the role of gender in shopping.

\section{Social shopping}

For decades, retailers and researchers have been aware that shopping is not just a matter of obtaining tangible products but also about experience, enjoyment and entertainment (Martineau 1958; Tauber 1972). Babin et al. (1994) classified shoppers into "utilitarian" (using cognitive processing to achieve shopping goals) vs. "hedonic" (shopping as emotional entertainment). Utilitarian shoppers like to save time and effort whilst shopping, whereas the enjoyment of the activity is more important for hedonic shoppers (Bellenger and Korgaonkar, 1980). Enjoyment and entertainment are significant benefits of shopping for consumers (Sit et al. 2003). Shopping is a social activity. As well as its functional role it includes the pleasure of browsing, impulse buying, discovering new shops, topic for casual conversation, focal point for planned and unplanned activities with other people. Researchers have drawn attention to the importance of social and affiliation motivations for shopping (e.g. Shim and Eastlick 1998; Westbrook and Black, 1985).

\section{Gender differences in shopping styles}

For women in particular, shopping has been reported to be a leisure and social activity in which they are more involved (Bakewell and Mitchell 2004; Dholakia 1999) and can express love for families and their social network (Miller 1998; Miller et al. 1998). For young women, socialising and entertainment are as important a part of their shopping trips as are shopping for goods and services (Haytko and Baker 2004). The female shopping style is said to involve searching, comparing, weighing the advantages and disadvantages of alternatives, 
finding the best value and taking a pride in the shopping activity (Dennis and McCall 2005; Underhill, 1999). On the other hand, men are said to see shopping as a mission and tend to go straight for what they want in a purposeful way (Dennis and McCall 2005; Underhill 1999). For men, the focus has been reported to be on the speed of the shopping process, achieved by sticking to familiar brands (also used by men as symbols of economic power) and by either visiting a familiar store and buying quickly or by being indifferent to which store is selected (Bakewell and Mitchell 2004). Women do most of the shopping; accounting for $73 \%$ of total spending in UK malls (Dennis et al. 2002b).

\section{Gender Differences in e-Shopping}

On the other hand, men make up the bulk of e-shoppers, shop online more frequently (Ballard 2006; OFT, 2007) and have more favourable perceptions of e-shopping than do women (Stark and Meier, 2001). Men may benefit from shopping online more than women do because it suits the purposeful masculine style more, e.g. finding the best deals quickly (Dennis and McCall 2005; Underhill 1999). One study reported that 22\% of men shop online at least once a week or more compared to $14 \%$ of women (OFT 2007). This indicates that retailers need to focus on how to encourage more women to shop online regularly, which is the reason why this study focuses on women's attitude and behaviour intentions towards social e-shopping sites.

\section{Social networking}

Social networks are online communities that allow people to socialise and interact with each other. These networks have made a significant impact in society and have changed the "social" lives of many young individuals. Nearly half (49\%) of all UK Internet users have used social networking at least once in the last year (and 70\% of people and households are Internet users) (Dutton et al./OxIS, 2009). Young females are over-represented as users of social network websites (Anonymous 2007; Social Networks 2007). Research carried out by Lenhart and Madden (2007) reported that $70 \%$ of girls use social network sites and $48 \%$ of teens visit social network websites like Facebook and MySpace daily.

Social network sites within the domain of internet communications technologies have altered the internet landscape for social interactions at both the interpersonal and community levels. Apart from Facebook and MySpace, there are many other social network sites including, for example, Bebo and Hi5. Social networking has become integrated into people's daily lives (Boyd and Ellison 2007). There are also countless work-based organisational and individual websites all over the world that incorporate a social component e.g. for alumni to link and

keep members, as well as encouraging new users to view and comment. These facilitate and encourage group connections.

Boyd and Ellison (2007) define social network sites as "web-based services that allow individuals to: (i) construct a public or semi-public profile within a bounded system; (ii) articulate a list of other users with whom they share a connection; and (iii) view and traverse their list of connections and those made by others within the system". Our trawl through social network sites suggests that they typically have in common the navigational tools within the sites that allow people to easily exchange or share their information, interests or activities. They can also allow advertisements via various interactive platforms for blogs and newsfeeds. There is an element of trust in such social network sites due to the privacy 
component being afforded where users can limit access to only those who have been invited to join their own profiles within the same network e.g. on MySpace or Facebook, thereby, building their own online community of friends. Users can upload their information content on their favourite things to share e.g. jokes, videos and music. The facilities provided by social network sites are a boon for users and recession-proof as the sites are usually free to use and are easy to navigate. Interestingly, usage appears to decrease with age as the largest proportion of users (54\%) is found in the 16-24 age group (Ofcom 2008). For the young generation of users, such social network sites have become a common online social activity. Students are in the active age group of virtual communities and therefore represent an appropriate age group for the study reported in this paper.

The retail marketing industry needs to face the challenge that it might miss out sections of young consumers who have either ignored or who are bypassed by traditional modes of offline marketing, particularly in mature and saturated markets, e.g. where direct marketing literature sent by post is typically addressed to heads of households or house owners. Faced with a wide array of older brand names and the constant proliferation of new ones, young consumers (e.g. teenagers to those aged in the twenties) are less inclined to believe advertised messages about benefits from competing companies. Rather, they are more likely to believe in real experiences which they can access online from their communities. Virtual communities can be a powerful marketing tool (Arnone et al. 2009). The power of word of mouth recommendations via social network sites is supported by DEI Worldwide (2008), who reported that $60 \%$ of social network users were likely to pass along information they received online. Moreover, two-thirds of users see online recommendations from others as valuable and credible, thus influencing brand perceptions and ultimately, purchase decisions (DEI Worldwide 2008).

In the following section we develop propositions concerning the likely preferences of females for social e-shopping. The research method for a qualitative study is explained, which explores the propositions with a comparison experiment, semi-structured questionnaire and focus group in order to compare a traditional e-shopping website with a social e-shopping one. Then we present the analysis and results of the research, indicating that young adult female shoppers find social e-shopping enjoyable and useful. The paper concludes with a discussion of the outcomes and their implications for academics and practitioners, suggesting that social e-shopping can be a valuable strategy for e-retailers.

\section{DEVELOPING PROPOSITIONS: SOCIAL E-SHOPPING}

We have argued above that many shoppers, particularly females, shop for social and hedonic benefits. The same may be true for e-shopping, where features like chat-rooms have been found to enhance the e-shopping experience (Parsons 2002). Palmer and Koenig-Lewis (2009) have argued that consumer-to-consumer relationships facilitated by social network websites are linked with hedonistic customer experiences. Despite the rapid growth of eretailing, these benefits are largely unavailable to e-shoppers and e-retailing is preferred by males for utilitarian reasons. At the same time, we have drawn attention to the growth of social networking, particularly amongst young females. Yet, anecdotal evidence and the empirical evidence that female shoppers' social needs are largely unmet led us to expect that female shoppers are currently not currently combining shopping with social networking to any extent, an activity that we define as "social e-shopping". Moreover, we also expect that 
social e-shopping is a major unmet need amongst young women and that there will be a strong preference for a social e-shopping website as opposed to a traditional e-retail site.

Based on these arguments, we expect that hedonic shoppers will prefer social e-shopping but utilitarian shoppers, too, should gain cognitive benefits such as knowledge of other shoppers' experiences with products. Therefore:

P1: Irrespective of shopping orientation, young adult females will prefer social eshopping as compared with traditional e-shopping.

This research focuses on women between 18-24 years old because they are the most dominant users of social networking sites (Anonymous 2007; Social Networks 2007) and they do not receive the social benefits they desire on many e-retailer websites (Dholakia 1999; OFT 2007).

\section{THEORETICAL FRAMEWORK: TECHNOLOGY ACCEPTANCE MODEL}

The Technology Acceptance Model (TAM) was originally developed for modelling users' acceptance of new technology in the workplace (Davis 1989; 1993). It has since proved to be a useful framework for explaining responses to e-retail websites (Chen et al. 2002; Dennis et al. 2009; Lee et al. 2005; Monsuwé et al. 2004). In TAM, "perceived enjoyment" (Davis et al. 1992), "perceived ease of use" and "perceived usefulness" are key factors that affect people's behaviour intention to adopt new technological innovations (Davis 1989; 1993). The main criticism of this model is that it excludes exogenous factors which are also influences of econsumer behaviour (Moon and Kim 2001), e.g. consumer traits. There are many likely traits affecting e-shopping behaviour. Obvious likely moderators include gender and age, which we control for by considering a sample only of young adult females. In this exploratory study, we look particularly at the social aspects of shopping and therefore consider investigation of the trait hedonic vs. utilitarian shoppers to be especially relevant.

\section{Enjoyment}

Based on the arguments above, social e-shopping will be an enjoyable experience for young adult female shoppers (e.g., Haytko and Baker 2004). Enjoyment is defined as the degree to which an experience is fun or interesting (Moon and Kim 2001), having three components: pleasure, arousal and escapism (Mathwick et al. 2001; Menon and Kahn 2002). The positive effects of pleasure and arousal on behavioural intentions have long been known (e.g., Mehrabian and Russell 1974) and have more recently been demonstrated also to be relevant to e-shopping (Eroglu et al. 2001; Eroglu et al. 2003). Studies revealed that enjoyment influences intention to return to a retailer's website (Liu and Arnett 2000; Koufaris 2002). Both Fiore et al. (2005), and Jayawardhena and Wright (2009) found that the enjoyment of websites had positive influences on behaviour response to e-retailer websites. The results of such studies would suggest that social e-shopping can provide women with a pleasing and arousing motivation that would encourage them to spend a longer duration, spend more money in and return more often to e-retail stores. Enjoyment positively affects consumers' attitudes towards e-shopping (Childers, 2001; Heijden and Verhagen 2004). Thus

P2: Perceived enjoyment of social e-shopping is positively related to women's attitudes towards e-retailer web sites; 
and

P3: Perceived enjoyment of social e-shopping is positively related to young women's intentions to shop on e-retailer websites.

We assume that young women's growing leisure use of social networking is at least partly due to their enjoyment of this activity. Therefore:

P4: Young women's perceived enjoyment of social e-shopping will be greater than that of traditional e-shopping.

\section{Ease of use}

Ease of use has been defined as "the individual's perception that using the new technology will be free of effort" (Monsuwé et al. 2004: 106), which we interpret in our context as women's perceptions that social e-shopping will involve minimum effort. Site characteristics and efficiency have been found to influence the "ease of use" of an online store (Zeithaml et al. 2000; 2002). According to Monsuwé et al. (2004: 106), "the easier and more effortless a technology is, the more likely consumers intend to use this technology". Individuals will feel more confident about a new technology if it is easy to use (Adams et al. 1992; Dennis et al., 2009). Jupiter Research (2006) found that almost one-third of participants were dissatisfied with e-retailers on account of their site being too confusing and about half of those would abandon the e-retail store on this account. On the other hand, two thirds of Internet users said that they would return to a website that is easy to navigate. If social e-shopping sites are perceived as "easy to use" then women are more likely to shop online and develop positive attitudes towards social e-shopping sites (Pavlou 2003; Chen and Tan 2004). Conversely, if a website is not easy to use then it can have a negative effect on consumers' perceptions and affect their attitude to return to the site (Rose 2001). Therefore:

P5: Perceived ease of use of social e-shopping is positively related to women's attitude toward retailer websites;

and

P6: Perceived ease of use of social e-shopping is positively related to women's intention to shop at retailer websites.

We expect that there is a link between ease of use and utilitarian type shoppers; if a website is easy to use then it saves time and effort for customers and provides them with a positive image of the website.

\section{Perceived Usefulness}

Usefulness can be considered as "the individual's perception that using the new technology will enhance an individual's experience" (Monsuwé et al. 2004: 105), or in this case, women's perceptions that social e-shopping will positively enhance their shopping experience and willingness to purchase from the site. Many studies show that "perceived usefulness" significantly impacts consumer behaviour intentions to use an e-retail site (e.g., 
Childers et al. 2001; Koufaris 2002; Vijayasarathy 2004). Similarly, "usefulness" has been found to influence attitude towards online stores and is linked with utilitarian shoppers (Lee et al. 2005). Saadé (2007) demonstrated that there are three dimensions of usefulness namely: performance-related outcome expectations; personal-related outcome expectations; and intrinsic motivation. Hence, if social e-shopping is considered useful, it would meet at least one of those dimensions among consumers. On the other hand, if a website is not useful then it can have a negative effect on consumers' perceptions and affect their attitudes to return to the site (Rose 2001). Hence:

P7: Perceived usefulness of social e-shopping is positively related to young women's attitude toward retailer websites

and

P8: Perceived usefulness of social e-shopping is positively related to young women's intention to shop at retailer websites.

Utilitarian shoppers like to save time and effort whilst shopping (Bellenger and Korgaonkar 1980), which they will be able to do on a social e-shopping virtual high street. Consumers use social networking to improve the quality of their purchase decisions by finding information and reducing risk in their selection decisions (Cole 2007). Young women's growing use of social networking may be partly due to their perceived usefulness of this activity. Therefore:

P9: Young women's perceived usefulness of social e-shopping will be greater than that of traditional e-shopping.

The e-retail experience is enhanced when consumers can use a variety of information cues in order to judge the quality of products they want to buy. This would also help in risk reduction when the consumer purchase decision is based on a variety of information to evaluate product quality. Most research on cue utilization theory has looked at offline studies and there is scarce literature about the impact of such theory in social network sites or their influences on shopping orientations. Various authors (e.g. Dodds et al. 1991; Richardson et.al. 1994; Dick et al. 1996; Grewal et al. 1998, Miyazaki et al. 2005) have reported on the impact of cues on the decision making processes of consumers to make inferences about the quality of products and services. Consumers can look at many cues in order to infer product quality such as: intrinsic cues about a product's physical attributes e.g. colour and texture; and the extrinsic cues about the related product attributes e.g. store name, brand name, price and promotions. Proposition 9, that young women's perceived usefulness of social e-shopping will be greater than that of traditional e-shopping, would fundamentally be important where social eshopping could be found to perpetuate or prolong discussion of information cues that allowed them to make inferences of product quality on social network sites.

The following section outlines the research method for a qualitative study that explores the propositions.

\section{METHOD}

This research concerns a complex area that has been little researched to date. Therefore, an exploratory qualitative approach that sought to provide insight into the underlying messages 
that consumers' experienced was indicated (Bellinger et al. 1976; Dey 1993). Qualitative research allows researchers to formulate interpretations of the subjects under study and to give representations of these interpretations in order to add to a body of knowledge (Wright 2008). This was operationalized in the form of semi-structured questionnaire and focus group. Focus groups are particularly appropriate for this type of research as they provide insight and depth into the attitude and behaviour intentions of a group of participants (Krueger 1994).

\section{Sample}

A convenience sample of 30 female undergraduate students aged 18 to 24 was drawn from a UK university. Student samples are well suited to e-shopping research, because they are computer literate (Balabanis and Reynolds 2001; Fiore et al. 2005) "shoppers of tomorrow" (Dennis et al. 2002a: 283). The profile of students is closer to that of the online customer population than is the profile of the general population and accepted as suitable subjects for technology acceptance studies (King and He 2006). All participants were experienced Internet users and e-shoppers.

Each participant had to take a hedonic-utilitarian pre-screening before the experiment in order to ensure that there were an equal number of hedonic and utilitarian shoppers represented (see below). Approximately 80 females needed to be pre-screened in order to achieve fifteen utilitarian shoppers.

\section{Shopping comparison experiment}

We set up a field experiment that allowed participants to feel comfortable in their surroundings (Chisnall 1996). Two websites were used: one was a traditional e-shopping website, Dorothy Perkins (www.dorothyperkins.co.uk) and the other a social e-shopping website, Osoyou (www.osoyou.com). The Dorothy Perkins website is a conventional e-retail website that can be readily found using most search engines. On this website, customers can easily search for items that they want to purchase through a search tool, enlarge product images, and gain relevant product information. The Dorothy Perkins website provides no social experiences for customers but the authors consider it to be a convenient place to shop and easy to navigate. This website was chosen because it is a popular website that caters for a wide range of female sizes, e.g. petite and tall, and a range of ages including young adults (Anonymous 2006). Osoyou is a social e-shopping website that has the benefits of a conventional e-shopping website and additional social attributes, providing many personalised benefits. This website enables customers to shop at many different e-stores such as Miss Selfridge, Oasis and Warehouse via links. Osoyou attempts to replicate a shopping experience similar to a "high-street", offering variety, quality and different price offers. Osoyou adopts the current trends of social networking through allowing customers to create groups, lists, style-files and meet people (shopping friends). This website was chosen for the experiment because as far as we are aware, is the UK's first social e-shopping website (UKPRwire 2007).

\section{Hedonic-utilitarian pre-screening}


Participants were pre-classified as either hedonic- or utilitarian-orientated using an adapted 10-item version of Babin's et al.'s (1994) scale (see Appendix, Table 1). As mentioned above, product classes (e.g. clothing vs. technical equipment) may have different influences on shopping motivation (Wang et al. 2007). We therefore controlled for this by requesting participants to consider only clothing shopping. Similarly, it was pointed out above that shoppers may follow both motives at different points in time (Holbrook and Hirschman 1982; Babin et al. 1994). Nevertheless, we wished to explore whether young adult females who are using e-shopping would self-classify themselves as utilitarian or hedonic shoppers, so we framed the questions accordingly.

\section{Experimental Procedures and Analysis}

From a pilot study, it was determined that participants required six minutes to make a confident evaluation of each website. In the initial stage, they were therefore allocated six minutes to thoroughly examine and report on their shopping experiences at each website. They were then questioned about their shopping experiences and preferences for e-shopping on each website. Each participant was given an "Experiment Evaluation Form" which had a unique code number. This was used as an identifier for those who returned for the focus group session, so that utilitarian- and hedonic-orientated shoppers could be identified throughout (whilst retaining anonymity).

\section{Focus Group}

A follow-up focus group was carried out with 10 of the participants from the first stage: five hedonic and five utilitarian shoppers, to explore further and add depth to the findings. The focus group participants were asked to explore both the traditional e-shopping (Dorothy Perkins) and social e-shopping (Osoyou) websites again prior the focus group session. As an incentive, participants were notified that a raffle ticket winner would be given a free $£ 10$ shopping voucher after they participated in the experiment and focus group session. Badges with code numbers were given to participants so that it was easy to identify who was a utilitarian or hedonic shopper for analysis purposes. The semi-structured discussion guide contained open-ended questions and cues in order to detect patterns and trends across the groups and encourage spontaneity. Sessions were recorded and later transcribed for analysis. A second researcher assisted the moderator by taking contemporaneous notes of what were judged to be key constructs.

After introductory questions such as "How did you find the experiment?" and "Do you enjoy shopping online?", A discussion of the key areas was stimulated by asking questions such as "what are the features that make social e-shopping enjoyable?" and "If you were actually shopping online for clothes would you go to Osoyou.com often?". Finally, the researcher asked participants to make recommendations.

We adopted a systematic approach to data analysis. This was considered preferable to a conversation analytic approach or group dynamics, which would have been likely to suppress useful findings as a result of digressing outside our sphere of investigation. Sorting and theme generation in the form of axial coding facilitated the listing of recurrent themes. Axial coding facilitated the process of listing key ideas, using a transcription form based on a standard template. The two researchers who respectively moderated and assisted with the focus group carried out the initial coding. Three other researchers read the transcripts and the five 
researchers agreed the final selection of quotes as indicative of consensus or minority views as appropriate.

\section{RESULTS}

\section{Utilitarian-hedonic shopping orientations}

In order to polarise self-classification, potential participants were given the opportunity of responding only "true" or "false" to the pre-screening questions. All were able to do this readily, with none trying to answer "in-between". Bearing in mind that shopping orientations might vary in degree and vary with time, this is a somewhat arbitrary distinction. Nevertheless, it is a useful one in practical terms, in eliciting viewpoints on social eshopping. Respondents were classified into "hedonic" or "utilitarian" categories based on whether they answered the majority of the questions in the appropriate direction. By the time that 15 hedonic shoppers were enrolled, only a single utilitarian shopper had been identified. As mentioned above, approximately 80 potential respondents had to be pre-screened in order to identify 15 utilitarian shoppers. In line with our expectations, most young adult female students in our sample were clearly hedonic in their shopping orientations and the categories were distinct.

\section{Prior use and awareness of social e-shopping}

None of the 30 participants were previously aware of or users of Osoyou or any other social e-shopping site, consistent with our expectations.

\section{Preference for traditional or social e-shopping}

The hedonic- and utilitarian-orientated shoppers shared similar evaluations of the Dorothy Perkins website and preferred the Osoyou e-retail website to the Dorothy Perkins one. The hedonic shoppers expressed stronger preferences for the Osoyou site than did the utilitarian ones. Utilitarian shoppers mentioned practical benefits of Osoyou. One utilitarian shopper mentioned the ease of finding special offers and discounts:

"Osoyou saves time in shopping, because instead of having to look through different websites

for their special offers and discounts, Osoyou selects it all for you, so that you can pick, choose and refuse".

Another utilitarian shopper referred to the benefit of creating a shopping list:

"I like the opportunity it gives to customers to create a style-file and save items in a shopping list that you can always return to in your spare time".

The utilitarian shoppers were also appreciative of the social benefits to an extent, with one commenting:

"Best of both worlds, I can choose to shop or socialise, it's my choice". 
A different utilitarian shopper mentioned social networking as a benefit:

"I like social network websites like Facebook and MySpace and I like shopping online, the fact that I can now have the benefits of both is a good combination".

Typical comments from various hedonic shoppers were emphatic about the hedonic benefits of Osoyou. For example, one hedonic shopper loved the fashion news:

"I found Osoyou enjoyable because of the features available on the website like fashion news; I absolutely love it and believe it's a very effective way of shopping".

Another hedonic shopper referred to the benefits of finding friends:

“There's so much to do...I even found my friend on it and created my own personal profile".

A different hedonic shopper mentioned (e-)social networking as substituting for the social aspects of social shopping in shopping centres:

"I'm being honest yea, I used to prefer shopping at shopping centres because of the social aspects, but now that I can socialise and shop online I prefer social [e-] shopping sites".

A further hedonic shopper drew attention to the ability of social e-shopping to inform fashion shopping choices:

"I don't usually like shopping online because I never know what my friends or boyfriend would think about clothes I want to buy or whether or not it is 'the latest hit', you get me? [all laugh]... social shopping websites will allow me to get opinions from my friends and buy fashionable items without having to think twice".

Consistent with P1, the consensus of both hedonic and utilitarian shoppers was that they were more likely to recommend and return to the Osoyou site in preference to the Dorothy Perkins one and more likely to purchase from that site.

Enjoyment and usefulness constituted the main reasons for preferences for the social eshopping site over the traditional one.

\section{Enjoyment}

Participants agreed that social e-shopping is enjoyable. Participants stated that the social networking features like fashion groups enhanced their online experience. They liked the fact that they can compare a variety of items from different shops, create style profiles and purchase items that their favourite celebrities wear. Perceived enjoyment of social e-shopping positively affected the attitude of consumers towards the website and caused a longer duration on the site. Osoyou was described as "appealing", "attractive", "exciting", "thrilling" and "fun". A typical comment referred to the enjoyment and the features:

"I found Osoyou enjoyable because of the features available on the website like getting the celebrity look". 
One participant spent extra time on the site because of the interactivity and features:

"Osoyou offers a lot of interactivity and I spent nearly $1 / 2$ hour last night checking out the website's many features".

Another mentioned finding Osoyou enjoyable and addictive, leading to spending longer on the site:

"Well, I don't know about everyone else, but I find traditional shopping websites boring and usually don't spend more than three minutes shopping online, whereas, in the [local shopping mall] I would spend up to 10 minutes in my favourite store; yesterday I spent a long time exploring Osoyou...over 15 minutes - it's really enjoyable and addictive”.

These results demonstrate that perceived enjoyment is associated with a positive attitude towards and preference for social e-shopping compared with traditional social e-shopping, consistent with $\mathrm{P} 2$ and $\mathrm{P} 4$.

\section{Ease of Use}

Participants found the traditional e-shopping website in this study easier to use than the social e-shopping website. Some respondents considered that shopping on traditional websites is "clearer" and "less clustered". Wide support was expressed for one participant's comment that:

"If I want to purchase 10 different items, each from a different store on Osoyou, this would mean that I have to create 10 different accounts for each store... this takes a lot of time...it's not convenient".

Some utilitarian respondents found many of the features on Osoyou distracting from their main goal (shopping) which affected their usability of the website, finding it "confusing", providing "too much information" and "not very functional". Specifically, one participant mentioned finding it difficult to socialise and e-shop at the same time:

"It's difficult socialising and shopping online at the same time. So the easier the website is, the better it will be for customers and first time users".

Even though participants were unanimous in positive opinion of the Osoyou site, they agreed that it needs to be easier to use:

"I think everyone here can agree that they would prefer social [e-] shopping to traditional [e]shopping to some extent [all agreed] they just need to make the site easy to use and facilitate for everyone's shopping styles... ." ... Researcher: "Do you mean all fashion orientations?" ... Group: "yea”.

Nevertheless, some hedonic shoppers did find Osoyou reasonably easy to use, with one commenting that:

"Social [e-]shopping is easy to use because the homepage tells you a lot of things that are available on the site, it's like a normal website ... it's really not that hard to use". 
These results demonstrate that perceived ease of use is associated with a positive attitude towards e-shopping (preferring traditional to social e-shopping on this dimension) consistent with P5.

\section{Usefulness}

In contrast to ease of use, many participants thought that the social e-shopping site was more useful than the traditional e-shopping site. Participants believed that the features available on the site made their experience more "effective" and "productive". Participants noted that features like being able to read customer reviews and receive style advice improved their purchasing choices. Utilitarian shoppers in particular felt that they could find precisely what they wanted quickly through browsing different stores on the same website (Osoyou). For example, one utilitarian shopper commented on the time saving:

\section{"It saves time because all the shops are on one site".}

Two utilitarian shoppers mentioned the usefulness of extra information:

"It shows the most popular and latest items available at each store which is useful".

"Social [e-]shopping is useful because they let you know who's wearing what [celebrity] and they offer fashion advice, all on the same site".

Hedonic shoppers also found the social e-shopping website useful, with one commenting, for example on the interactivity:

"The fact that it's interactive would cause me to tell others about the site and encourage them to create a [style] profile...it's more productive than other sites".

However it was felt that the website needed to represent different fashion orientations in order to be more useful to everyone. One participant commented, for example:

"There are not many shops available on Osoyou.com that people my age like to shop at like $H \& M$ and River Island so I didn't find it too useful...they had no sportswear!”

There was no link between ease of use and usefulness in participant's responses in that an eshopping website can still be useful even if it is not easy to use.

These results demonstrate that perceived usefulness is associated with a positive attitude towards and preference for social e-shopping compared with traditional e-shopping, consistent with P7 and P9.

\section{Behaviour intention towards social e-shopping and intention to return to Osoyou}

Participants agreed that enjoyment, ease of use and usefulness affected their behaviour intentions to e-shop. Participants felt that enjoyment and usefulness were the main factors that would lead them to return to the Osoyou site, recommend and purchase. A typical comment on likely repurchase came from a utilitarian shopper: 
"Osoyou offers everything a girl wants, so it's the kinda site I would return to make a purchase".

One utilitarian shopper commented that other shoppers' opinions would influence buying:

"Shopping at Osoyou would enable me to view different opinions before I buy something....so I would return to the site and perhaps recommend it".

Another utilitarian shopper mentioned that the usefulness of the information would encourage them to use the site again:

"I would visit Osoyou again because it's a site that is very useful for shoppers and provides the information I always want to know".

Utilitarian shoppers also valued Osoyou for access to discounts and special offers, with one commenting:

"I would return definitely to see the latest offers and browse".

Hedonic shoppers were emphatic about intentions to continue to use social e-shopping, both for browsing and buying, with two commenting, for example:

"The features on the website would encourage me to revisit the site more regularly in the future. Personally, it's a very useful website”.

"I would feel motivated to shop online more often if normal retail websites had social shopping available".

\section{Intention to Purchase}

Some participants would rather purchase products from a traditional website. The main reason for shoppers preferring to purchase from a traditional website is that Osoyou was considered difficult to use. Three different shoppers commented, for example:

"I would prefer to shop on a website that I'm more...let's say familiar with and confident in terms of purchasing".

"If the site was more user-friendly then I would make purchases in future".

“To me, purchase, is linked to ease of use, so coz it's not easy to use, I won't purchase a lot of products from it, [Osoyou]... I'll get too frustrated".

Perceived ease of use would appear to be a factor in young women's intentions to e-shop (P6) but the preference for the ease of use of the traditional e-shopping site is largely outweighed by the enjoyment and usefulness of the social e-shopping site. Many participants said that they would be willing to buy many items through social e-shopping sites like Osoyou. It was variously suggested that the following increased their purchase intention on Osoyou: the 
usefulness of the website, ability to read reviews, seek approvals from others, and view the latest fashion trends. Two utilitarian shoppers mentioned a price and discount comparison advantage:

"I would buy products from Osoyou because they show a lot of promotions and discounts which as a student, is good for me”.

"Osoyou saves time in shopping, because instead of having to look through different websites for their special offers and discounts, Osoyou selects it all for you, so that you can pick, choose and refuse".

Some of the most emphatic intentions to purchase came from the hedonic shoppers, with one typically commenting on the social benefits:

"I would purchase and recommend my friends because it would be nice to socialise with my friends on Osoyou".

Two hedonic shoppers mentioned, for example, the motivation of following what is new:

"It's hard not to return to the website, you'll always want to know what's the latest, what's going on...I would most likely return and make a purchase".

"It makes me look at Marks and Spencer and let's say, Body Shop [linked from Osoyou] in a different way... a more positive image, it makes me want to buy something and always check out what's new".

\section{Intention to Recommend}

Many participants commented that they would recommend Osoyou to others, particularly friends and family, mainly because it is useful and enjoyable. A utilitarian shopper commented:

"The store offers a high street experience for people, its really different...you get to do all your shopping from other stores through one website ... I would most likely purchase many items from this site... and recommend".

Hedonic shoppers were particularly influenced by the social networking features, commenting for example on the fashion guru benefit:

"I would recommend people I know to Osoyou coz I know that they would benefit a lot from shopping there ...it's like a fashion guru site”.

Comments from two other hedonic shoppers were typical:

"I didn't know that there was a social [e-]shopping website! I told all my friends about it on Facebook and asked them to join”.

"I would recommend Osoyou to my friends so that we can socialise and shop together". 
These results demonstrate that enjoyment and usefulness of social e-shopping are positively related to young women's intentions to shop on social e-shopping sites, consistent with P3 and P8. The excitement generated by social [e]-shopping websites prompted intrinsic cues about joining and shopping together on "a fashion guru website" and "Facebook", and extrinsic cues relating to recommendations of the brand name of Osoyou, in order to make inferences of store quality on social network sites. The findings are consistent with P9, that young women's perceived usefulness of social e-shopping will be greater than that of traditional e-shopping.

\section{DISCUSSION}

The results of this study indicate that the majority of both utilitarian and hedonic shoppers prefer social e-shopping as opposed to other traditional sites. It was clear that there were individual differences in how women will use social e-shopping sites especially in terms of their shopping orientation (potentially extending Babin's et al's. 1992 shopping orientations to e-shopping). Hence, it can be suggested that female hedonic shoppers will use social eshopping sites for the entertainment aspect, whereas utilitarian shoppers will use these sites to increase their shopping productivity.

Perceived enjoyment has a fundamental effect on participants' attitude and behaviour intentions, supporting previous research (Childers 2001; Dholakia, 1999; Heijden and Verhagen 2004; Lee et al. 2005; Mathwick et al. 2001; Menon and Kahn 2002). The results are in line with our expectation that enjoyment via e-shopping is important for young women. The specific aspects that participants mentioned as enjoyable included high interactivity and range of features. Enjoyable features included that they can compare a variety of items from different shops and purchase items that their favourite celebrities wear. Other websites such as www.zappos.com can compare items from other shops but few include the facility to chat about celebrities. Women like websites that allow them to socialise, supporting previous research by Parsons (2002). Specific preferences of hedonic shoppers include: finding friends; substituting for the social aspects of social shopping in shopping centres; and informing fashion shopping choices.

Perceived ease of use affects the attitude and behaviour intention of young women, supporting the prior findings of Monsuwé et al. (2004). The social e-shopping website in this study was perceived as difficult to use, particularly because if they want to purchase 10 different items, each from a different store on Osoyou, this would mean that they have to create 10 different accounts for each store. Utilitarian shoppers also had negative comments concerning the layout of the site, in that the extra information and features distracted them from their main goal (shopping).

Similarly, perceived usefulness affects the attitude and behaviour intention of young women, again supporting the prior findings of Monsuwé et al. (2004). Even though Osoyou was seen not to be easy to use, participants still viewed the site as useful. Utilitarian shoppers valued extra information, particularly on the most popular and latest items available and time saving because all the shops are on one site. Shoppers also considered it useful to access fashion advice and know which what celebrities are wearing. Hedonic shoppers additionally found the socialising useful. 
In sum, the additional information of the Osoyou website contributed to a positive effect for all shoppers, whereas the social character of the sites appealed to the hedonic shoppers (whom we expect to be in the majority amongst young women).

\section{MANAGERIAL IMPLICATIONS}

The preferences of the young adult females in this study strongly favoured the social eshopping website over the traditional one, yet previously, the participants were unaware of the existence of social e-shopping. The results indicate that social e-shopping can encourage customers to return to the site, purchase and recommend. First, retailers targeting young adult females could be well advised to participate in or host social e-shopping websites, focusing design on enjoyment and usefulness. Second, the availability of such site(s) needs to be publicised more widely through customer education campaign(s). Third, social e-shopping websites need to be easier to use than the Osoyou site studied here, which should increase purchase intentions.

Enjoyment for this customer group may be increased by including more social networking facilities on customer profiles, which could cause customers to spend a longer duration on the e-retailer site. For example, features like being able to hug and send gifts to others could be included. Games and music are other fun elements that could attract more young people to use social e-shopping sites

e-Retailers might improve the usefulness of social e-shopping websites by incorporating image interactivity systems (Fiore et al. 2005), creating ways for people to envisage wearing their clothes and try on make-up with virtual mirrors through creating an association with other websites like My Virtual Model (www.myvirtualmodel.com) and EZFace (www.ezface.com) (Dennis et al. 2004). This could enhance the social e-shopping experience further as these images can be passed on to friends and family. Product selectivity can be made more useful by incorporating techniques such as zoom and 3D options and an avatar virtual assistant to provide information (Algharabat and Dennis 2010).

The availability of social e-shopping websites could be publicised to this target group through viral marketing, blogs, Facebook, Twitter and so on - the preferred means of communication for these young adult females (Lenhart and Madden 2007).

Ease of use of social e-shopping can be improved by systems to ensure a single logon and payment account for all participating retailers, rather than having to login to each one separately.

\section{LIMITATIONS AND FUTURE RESEARCH}

The empirical part of this research is limited to a qualitative study with a non-random sample. Moreover, the "standard" e-shopping site, Dorothy Perkins was previously known to the subjects, whereas the social e-shopping site, Osoyou, was not. This may have affected participants' evaluations of the differences between the two sites. Nevertheless, this study has served to illustrate the concept and likely acceptability of social e-shopping. More research is recommended to evaluate the propositions developed here and extend the generalisability to a larger group. 
Future research is recommended on ways of improving ease of use on social e-shopping websites. Also, this study has considered only young adult females, as an important shopping and social networking segment. Nevertheless, more research is recommended to investigate males and a wide range of age groups that also participate in both these activities.

\section{CONCLUSIONS}

In this paper, we have argued that shoppers, particularly women, are motivated by a variety of different reasons, including socialising and enjoyment. Despite the growth of e-retailing, the social needs, particularly of young adult females, are mainly not being met in e-shopping, which tends thus to be dominated by male shoppers. We have therefore developed propositions concerning social e-shopping, based on combining e-shopping with social networking. First, based on conventional shopping theory, we suggest that young female adults can be segmented into two distinct shopping orientations: utilitarian (minority) and hedonic (majority) shopping orientations. Anecdotal evidence and the empirical evidence that female e-shoppers' social needs are largely unmet led us to expect that most young female adults are currently not using social e-shopping but irrespective of their shopping orientation, young adult females will prefer social e-shopping to traditional e-shopping. Extrapolating TAM to the e-shopping domain, we propose that perceived enjoyment of social e-shopping is positively related to young women's attitude towards and intentions to shop on retailer web sites and that young women's perceived enjoyment of social e-shopping will be greater than that of traditional e-shopping. Similarly, we propose that perceived ease of use of social eshopping is positively related to young women's attitude toward and intention to shop at eretailer websites. Finally, we propose that perceived usefulness of social e-shopping is positively related to young women's attitude toward and intention to shop at e-retailer websites and that young women's perceived usefulness of social e-shopping will be greater than that of traditional e-shopping.

The results of our qualitative study are consistent with the propositions, with the young women in the sample indicating emphatically that perceived enjoyment and usefulness of social e-shopping was greater than that of traditional e-shopping. This study makes a contribution as there are limitations in the existing literature about the intrinsic and extrinsic shopping needs of females in the online social network context. Internet price comparison websites, such as Go Compare (www.gocompare.com), allow people to compare prices. While females can generate price comparisons and value for money on such websites, the enjoyment and discussions via e-word of mouth pursuits mean that their shopping experiences are better replicated when they invite others to join them for shopping on social network sites. Product utilization cue theory is also found to be very limited in the existing literature for online research. Therefore our study contributes in drawing attention to the importance of intrinsic and extrinsic cues in inferring product and store qualities. There are far more positively expressed intentions to return to, purchase from and recommend the social e-shopping site compared with the traditional one by females in our sample. Therefore, our presentation of the overall proposition of combining e-shopping with social networking into "social e-shopping" is appropriate for research given the developing e-retail landscape.

\section{ACKNOWLEDGEMENTS}

The authors thank the editors and anonymous reviewers for many helpful suggestions. 


\section{REFERENCES}

Adams, D. A., Nelson, R. R. and Todd, P. A. (1992), "Perceived usefulness, ease of use and usage of information technology: a replication", MIS Quarterly, Vol. 16, No. 2, pp. 227-247.

Algharabat, R. and Dennis, C. (2010), 'Using Authentic 3D Product Visualisation for an Electrical Online Retailer', Journal of Customer Behaviour, this issue.

Anonymous. (2006), "Dorothy Perkins Profile" [online], available at: http://www.linemypocket.co.uk/dorothy-perkins.htm, [accessed: $20^{\text {th }}$ February 2008].

Anonymous. (2007) "Young women dominate the UK net scene", BBC News Technology [online], available at: http://news.bbc.co.uk/1/hi/technology/6662469.stm [accessed: 1st December 2007].

Arnone, L., Geerts, A. and Scoubeau, C. (2009), "Implementing company-managed virtual communities as a relationship marketing tool: a decision systems analysis" Journal of Customer Behaviour, Vol. 8, No. 1, pp. 5-27.

Babin, B.J., Darden, W.R. and Griffin, M. (1994), "Work and/or fun: measuring hedonic and utilitarian shopping", Journal of Consumer Research, Vol. 20, No. 4, pp. 644-656.

Ballard, E. and Mander, S. (2006), "It's Official, Men Shop More than Women", SciVism Web Application Testing [online], Press Release, available at: http://www.scivisum.co.uk/pressreleases/200609malefemale_ecomm.htm [accessed 18th October 2007].

Bakewell, C. and Mitchell, V.-W. (2004), "Male consumer decision-making styles", International Review of Retail, Distribution and Consumer Research, Vol. 14, No. 2 pp. 223-240.

Balabanis, G., and Reynolds, N. L. (2001), "Consumer Attitudes Towards Multi-Channel Retailers" Web Sites: The Role of Involvement, Brand attitude, Internet Knowledge and Visit Duration", Journal of Business Strategies, Vol. 18 (Fall), pp. 105-131.

Bellinger, D. N., Bernhardt, K. L., and Goldstucker, J. L. (1976), Qualitative Marketing Research, Chicago: American Marketing Association.

Bellenger, D. N. and Korgaonkar, P. K. (1980), "Profiling the recreational shopper", Journal of Retailing, Vol. 56, pp. 77-92.

Boyd, D. M. and Ellison, N. B. (2007), "Social network sites: Definition, history, and scholarship", Journal of Computer-Mediated Communication [online], Vol. 13, No. 1, article 11, available at: http://jcmc.indiana.edu/vol13/issue1/boyd.ellison.html [accessed 29 August 2009].

BRC. (2010), BRC-KPMG Retail Sales Monitor April 2010 [online], London: British Retail Consortium, available at: www.brc.org.uk posted 13 April 2010 [accessed 22 April 2010].

Chen, L, Gillenson, M. L. and Sherrell, D. L. (2002), "Enticing Online Consumers: an Extended Technology Acceptance Model Perspective", Information and Management, Vol. 39, No. 8, pp. 705-719.

Chen, L. D. and Tan, J. (2004), "Technology Adoption in E-commerce: Key Determinants of Virtual Store Acceptance", European Management Journal, Vol. 22, No.1, pp. 74-86.

Childers, T. L., Carr, C. L., Peck, J and Carson, S. (2001), "Hedonic and Utilitarian Motivations for Online Retail Shopping Behaviour", Journal of Retailing, Vol. 77, pp. 511-535.

Chisnall, P.M. (1996), Marketing Research, Berkshire: McGraw-Hill.

Cole, M. (2007), "The networked consumer: a critical review and assessment", Journal of Customer Behaviour, Vol. 6, No. 1, pp. 5-18. 
Davis, F. D. (1993), "User Acceptance of Information Technology: System Characteristics, User Perceptions and Behavioural Impacts", International Journal of Man-Machine Studies, Vol. 38 No. 3, pp. 475-487.

Davis, F. D., Bagozzi, R. P. and Warshaw, P. R. (1992), "Extrinsic and Intrinsic Motivation to use Computers in The Workplace", Journal of Applied Social Psychology, Vol. 22, No. 14, pp. 1109-1130.

Davis, F. D. Bagozzi, R. P., and Warshaw, P. R. (1989) "User acceptance of computer technology: a comparison of two theoretical models", Management Science, Vol. 35, No. 8, pp. 982-1003.

Dennis, C., Fenech, T. and Merrilees, W. (2004), e-Retailing, Abingdon and New York: Routledge.

Dennis C, Harris L and Sandhu B, (2002a), 'From Bricks to Clicks: Understanding the eConsumer', Qualitative Market Research - An International Journal, Vol. 5, No. 4, pp. 281-290.

Dennis, C., Jayawardhena, C., Merrilees, W. and Wright, L. T. (2009), e-Consumer Behaviour, European Journal of Marketing, Vol. 43, Nos. 9/10, pp. 1121-1139.

Dennis, C. E.; Murphy, J., Marsland, D., Cockett, W. and Patel, T. (2002b), "Measuring Image: Mall Case Studies", International Review of Retail, Distribution and Consumer Research, Vol. 12, No. 4, pp. 353-373.

Dennis, C. and McCall, A. (2005) "The savannah hypothesis of shopping", Business Strategy Review, Vol. 16, No. 3, pp. 12-16.

Dey, I. (1993), Qualitative Data Analysis, London: Routledge, pp. 262-263.

Dholakia, R. R. (1999), "Going shopping: key determinants of shopping behaviour and motivations", International Journal of Retail and Distribution Management, Vol. 27, Nos. 4-5, pp. 154.

Dick, A. S., Jain, A. K. and Richardson, P. S. (1996) "How consumer evaluate store brands", Journal of Product and Brand Management, Vol. 5, No. 2, pp. 19-28.

DEI Worldwide, (2008), "Engaging consumers online. The impact of social media on Purchasing behaviour; Volume one: initial findings United States 2008" [online], available at: http://www.deiworldwide.com/files/DEIStudyEngaging\%20ConsumersOnline-Summary.pdf [accessed $29^{\text {th }}$ August].

Dodds, B. W., Monroe, B. K. and Grewal, D. (1991), "Effects of Price, Brand, and Store Information on Buyers" Product Evaluations", Journal of Marketing Research, Vol. 28, No. 3, pp. 307-319.

Dutton, W. H., Helsper, E. J. and. Gerber, M. M. / OxIS. 2009. The Internet in Britain 2009, Oxford: Oxford Internet Surveys / Oxford University, available at: www.oii.ox.ac.uk/microsites/oxis/ [accessed 21 April 2010].

Eroglu, S. A., Malcheit, K. A. and Davis, L. M. (2001), "Atmospheric Qualities of Online Retailing: A conceptual Model and Implications", Journal of Business Research, Vol. 54 No. 2, pp. 177-184.

Eroglu, S. A., Machleit, K. A. and Davis, L. M. (2003), "Empirical Testing of a Model of Online Store Atmospherics and Shopper Responses", Psychology and Marketing, Vol. 20, No. 2, pp. 139-150.

Fiore, A. M., Jin, H. and Kim, J. (2005), "For fun and profit: Hedonic value from image interactivity and responses toward an online store", Psychology and Marketing, Vol. 22, No. 8 pp. 669-694.

Grewal, D. R., Krishnan, J. B. and Norm, B. (1998), "The effect of store name, brand name and price discounts on consumers' evaluations and purchase intentions", Journal of Retailing Vol. 74 No. 3, pp. 331-352.

Haytko, D. L. and Baker, J. (2004), "It's all at the mall: exploring adolescent girls' experiences", Journal of Retailing, Vol. 80, pp. 67-83. 
Heijden, H. and Verhagen, T. (2004), "Online Store Image: Conceptual Foundations and Empirical Measurement", Information and Management, Vol. 41, No. 5, pp. 609-617.

Holbrook, M. B. and Hirschman, E. C. (1982), "The Experimental Aspects of Consumption: Consumer Fantasies, Feelings, and Fun”, Journal of Consumer Research, Vol. 9, September, pp. 132-140.

IMRG/Capgemini. (2010), IMRG Capgemini eRetail Sales Index: April 2010 [online], posted 22 April 2010, available at: http://www.imrg.org London: IMRG Capgemini [accessed 22 April 2010].

Jupiter Research (2006), Retail Web Site Performance: Consumer Reaction to a Poor Online Shopping Experience [online], available at: http://www.jupiterresearch.com, [accessed $20^{\text {th }}$ February 2008].

King, W. R. and He, J. (2006), A meta-analysis of the Technology Acceptance Model. Information and Management, Vol. 43, pp. 740-755.

Kolesar, M. B. and Galbraith, R. W. (2000), "A services-marketing perspective on eretailing: implications for e-retailers and directions for further research", Internet Research: Electronic Networking Applications and Policy, Vol. 10, No. 5 pp. 424438.

Koufaris, M. (2002), "Applying the Technology Acceptance Model and flow theory to online behaviour”, Information Systems Research, Vol. 13, No. 3, pp. 205-223.

Kruegar, A. R. (1994), Focus Groups: A Practical Guide for Applied Research, second edition, London: Sage.

Lee, H., Fiore A., Kim, J. (2005), "The role of the Technology Acceptance Model in explaining effects of image interactivity technology on consumer responses", International Journal of Retail and Distribution Management, Vol. 4, No. 8, pp. 621624.

Lenhart, A. and Madden, M. (2007), "Pew Internet and American Life Project: Social Networking Websites and Teens: An Overview", [online] available at: http://www.pewinternet.org/pdfs/PIP_SNS_Data_Memo_Jan_2007.pdf [accessed: 20th October, 2007).

Liu, C. and Arnett, K.P. (2000), "Exploring the factors associated with Web site success in the context of electronic commerce", Information and Management, Vol. 38, pp. 2333.

McGoldrick, P. J. (2002), Retail Marketing, Berkshire: McGraw-Hill.

Martineau, P. (1958), "The personality of the retail store", Harvard Business Review, Vol. 36 No. 1, pp. 47-55.

Mathwick, C., Malhotra, N.K. and Rigdon, E. (2001) "Experiential value: conceptualization, measurement and application on the catalog and internet shopping environment", Journal of Retailing, Vol. 77, No.1, pp. 39-56.

Miller, D., Jackson, P., Thrift, N., Holbrook, B. and Rowlands, M. (1998), Shopping, Place and Identity, London: Routledge.

Menon, S., and Kahn, B. (2002), "Cross Category Effects of Induced Arousal and Pleasure on the Internet Shopping Experience", Journal of Retailing, Vol. 78, No. 1, pp. 31-40.

Mehrabian, A. and Russell, J. A. (1974), An Approach to Environmental Psychology, Cambridge, MA: MIT Press.

Miller, D. (1998), A Theory of Shopping, London: Polity.

Miyazaki, A. D., Grewal, D. and Goodstein, R. C. (2005), “The Effect of Multiple Extrinsic Cues on Quality Perceptions: A Matter of Consistency", Journal of Consumer Research, Vol. 32, No.1, pp.146-153. 
Monsuwé, T. P., Dellaert, B. G. C. and de Ruyter, K. R. (2004), "What drives consumers to shop online? A literature Review", International Journal of Services Industry Management, Vol. 15, No. 1, pp. 102-121.

Moon, J. M. and Kim, Y. G. (2001), "Extending the TAM for a world-wide web context", Information and Management, Vol. 28, No. 4, pp. 217-230.

Ofcom (2008), "The Communications Market 2008", [online] http://www.ofcom.org.uk/research/cm/cmr08 [accessed 29th August 2009].

OFT (2007), "Internet Shopping" [online], OFT Market Study, available at: http://www.oft.gov.uk/shared_oft/reports/consumer_protection/oft921.pdf [accessed: $3^{\text {rd }}$ November 2007].

Palmer, A. and Koenig-Lewis, N. (2009), "An extended, community focused, experiential framework for relationship marketing”, Journal of Customer Behaviour, Vol. 8, No. 1, pp. 85-96.

Parsons, A. G. (2002), "Non-functional motives for online shoppers: why we click", Journal of Consumer Marketing, Vol. 19, No. 5, pp. 380-392.

Pavlou, P. A. (2003), "Consumer Acceptance of Electronic Commerce: Integrating Trust and Risk with Technology Acceptance Model", International Journal of Electronic Commerce, Vol. 25, No. 4, pp. 329-346.

Private Label Manufacturers Association (2009), PLMA's Private Label Yearbook: Private label increases market share as Europe's shoppers seek more value [online], available

at: http://www.plmainternational.com/pressupdate/pressupdate_new02.asp?language=en [accessed $29^{\text {th }}$ August 2009].

Richardson, P. S., Dick, A. S. and Jain, A. K. (1994), "Extrinsic and intrinsic cue effects on perceptions of store brand quality", The Journal of Marketing, Vol. 58, No. 4, pp. 2836.

Rose, G. M. and Straub, D. W. (2001), "The effect of download time on consumer attitude toward the e-service retailer", e-Service Journal, Vol. 1, No. 1, pp. 55-76.

Saadé, G. R. (2007) "Dimensions of perceived usefulness: towards enhanced assessment", Decision Sciences Journal of Innovative Education, Vol. 5, No. 2, pp. 289 -310.

Seock, Y.-K. and Bailey, L. R. (2007), "The influence of college students" shopping orientations and gender differences on online information searches and purchase behaviours", International Journal of Consumer Studies, Vol. 32, No. 2, pp. 113-121.

Shim, S. and Eastlick, M. A. (1998), "The hierarchical influence of personal values on mall shopping attitude and behaviour", Journal of Retailing, Vol. 74, No. 1, pp. 139-160.

Sit, J., Merrilees, W., and Birch, D. (2003), "Entertainment-seeking shopping centre patrons: the missing segments", International Journal of Retail and Distribution Management, Vol. 3, No. 2, pp. 80-94.

Social Networks, (2007), "Gender and Friending: An Analysis of MySpace Member Profiles" [online], available at: http://www.scit.wlv.ac.uk/ cm1993/papers/MySpace_d.doc [accessed $20^{\text {th }}$ October 2007).

Stark, J. and Meier R. (2001), "A longitudinal study of usage and satisfaction levels of internet shopping by college students", Journal for Computer Information Systems, Vol. 41, No. 4, pp. 65-68.

Tauber, E. M. (1972), “Why do people shop?” Journal of Marketing, Vol. 36 (Oct.), pp. 4659.

UKPRwire, (2007) "OSOYOU.COM, Announces Content Team" [online], available at: http://www.ukprwire.com/Detailed/Advertising_Marketing/OSOYOU.com_announce s_Content_Team_7067.shtml [accessed $3^{\text {rd }}$ October 2007).

Underhill, P. (1999), Why We Buy, London: Orion. 
Vijayasarathy, L. R. (2004), "Predicting consumer intentions to use online shopping: the case for an augmented technology acceptance model", Information and Management, Vol. 41, No. 6, pp. 747-762.

Wang, P., Baker, J., Wagner, J. A. and Wakefield, K. (2007), "Can a Retail Website be Social?", Journal of Marketing, Vol. 71, No. 3, pp. 143-157.

Westbrook, R. A. and Black, W. C. (1985), "A motivation-based shopper typology", Journal of Retailing, Vol. 61, No. 1, pp. 78-103.

Wright, L. T. (2008), "Qualitative Research", Chapter 9 in Baker, M., ed., The Marketing Textbook 6th edition, Oxford: Elsevier.

Zeithaml, V., Parasuraman, A. and Malhorta, A. (2000), “A conceptual framework for understanding e-service quality: implications for future research and managerial practice", Marketing Science Institute Working Paper Series, 00.115.

Zeithaml, V., Parasuraman, A. and Malhorta, A. (2002), "Service Quality and Delivery through Web-sites: a critical review of extant knowledge", Journal of the Academy of Marketing Sciences, Vol. 30, No. 4, pp. 362-275. 


\section{Appendix}

\section{Table 1: Screening for utilitarian vs. hedonic shopping orientations}

Respondents were asked to answer 'true' or 'false' to the following, with respect to clothes shopping:

1. I like to shop because I find it enjoyable, even if I buy more than intended ('true' = hedonic).

2. I like shopping only if it is useful e.g. my shoes are old, now I need new ones (utilitarian).

3. I like shopping because I find it an escape from ordinary life (it's my time!) (hedonic).

4. I do not like to browse, I like to go straight for what I want then go home (utilitarian).

5. I do not care about the shopping experience, as long as I get what I want (when I'm shopping) as soon as possible, then I'm happy (utilitarian).

6. The shopping experience really matters to me such as interacting with friends, browsing etc. these factors motivate me to shop more (even if I come home with nothing) (hedonic).

7. I find shopping exciting, it's something that I look forward to do with or without friends (hedonic).

8. I like to shop as quickly as possible (don't have time to waste) (utilitarian).

9. I like to buy only what I need when I'm shopping, so I don't get distracted by other items (utilitarian).

10. I like shopping at many different stores to compare items before I purchase (hedonic). Source: Adapted from Babin et al. (1994). 